\title{
IAMJ
}

INTERNATIONAL

AYURVEDIC

MEDICAL JOURNAL

ISSN: 2320-5091

Impact Factor: 6.719

\section{AYURVEDIC MANAGEMENT OF ADENOMYOSIS - A CASE REPORT}

\author{
Shivakumaraswamy P', Seema Yadav ${ }^{2}$, Deepthi. G. B ${ }^{3}$, Sindhu Umesh ${ }^{4}$ \\ ${ }^{1}$ Assistant Professor Department of Prasuti Tantra and Stree roga, Sri Paripoorna Sanathana Ayurveda Medical \\ College Hospital \& Research Centre Nelamangala, Karnataka, India \\ 23rd Year PG Scholar, Department of Prasuti Tantra and Stree roga Sri Dharmasthala Manjunatheshwara College of \\ Ayurveda and Hospital, Hassan, Karnataka, India \\ ${ }^{3}$ Deepthi. G. B, 3rd Year PG scholar, Department of Prasuti Tantra and Stree Roga Sri Dharmasthala \\ Manjunatheshwara College of Ayurveda and Hospital, Hassan, Karnataka, India \\ ${ }^{4}$ Assistant Professor, Department of Prasooti Tantra Evam Stree Roga, Sri Dharmasthala Manjunatheshwara \\ College of Ayurveda and Hospital, Bangalore, Karnataka, India
}

Corresponding Author: drshivakumaraswamyp5@gmail.com

https://doi.org/10.46607/iamj15p5042021

(Published online: May 2021)

Open Access

(C) International Ayurvedic Medical Journal, India 2021

Article Received: 29/04/2021 - Peer Reviewed: 06/05/2021 - Accepted for Publication: 07/05/2021

Check for updates

\section{ABSTRACT}

Most of the women are suffering from one or other menstrual problem in their life, Adenomyosis is also one among them. In general, Adenomyosis is defined as presence of endometrial tissue within the myometrium. It is described as circumscribed nodular aggregate of smooth muscle and endometrial glands with compensatory hypertrophy of the myometrium surrounding the ectopic endometrium ${ }^{1}$. It is associated with menorrhagia or menometrorrhagia and congestive dysmenorrhoea. In Ayurvedic text 20 yoni Vyapads are explained, among them Vipluta is one of them characterised with constant pain associated with other pains of Vata Prakopa ${ }^{2}$. So, in this case we diagnosed the case as Vipluta Yonivyapad and treated with the same line of treatment, which got promising result.

Keywords: Adenomyosis, Yoni Vyapad, Vipluta Yoni Vyapad. 


\section{INTRODUCTION}

Adenomyosis is characterised by uterine enlargement caused by ectopic rests of endometrium, both glands and stroma located deep within the myometrium. These rests may be scattered throughout the myometrium diffuse Adenomyosis or they may from a circumscribed nodular focal collection - focal adenomyosis.

Approximately one third of women with Adenomyosis have symptoms in which menorrhagia and dysmenorrhoea are common. Dysmenorrhoea is thought to be caused by increased prostaglandins production found in Adenomyosis tissue compared with that in normal myometrium $^{3}$.

In India the prevalence of Adenomyosis is $23.5 \%$ in which $80 \%$ were seen in the age group of $31-50 y$ rs.

Here in this study we have correlated Adenomyosis with Vipluta Yoni Vyapad because of the characteristic feature is Nitya Vedana as described by Acharya Sushrutha, which is due to increased Vata Dosha which we can correlate with dysmenorrhoea in Adenomyosis. Because of Vata predominance there will be disturbance in the myometrium.

And hence the main line of treatment chosen is Vata -

Pitta Shamaka and Vata Anulomaka.

\section{Case Report-}

A 48yr old married female came to OPD of Prasooti tantra and Stree Roga, at SDM Hassan with complains of dull aching pain in lower abdomen since 1yr, associated with $\mathrm{p} / \mathrm{v}$ excessive bleeding during menstruation and increased pain during menstruation.

History of present illness-

Patient was apparently healthy one year back. Later she developed localised mild pain in lower abdomen and simultaneously she was having excessive bleeding during her menses and the pain increased during menstruation. Gradually she developed irregular menstrual cycle for which she took Allopathy treatment for 3 months (details of which not available) but there was no relief and she was suggested for hysterectomy and she denied for the surgical intervention. Then she consulted PTSR OPD at SDM Hassan for the further management.

Past history- nothing significant

Family history- nothing significant
Personal history- appetite - good

Diet- mixed (spicy and salty

Nonveg twice in a weak mainly chicken)

Bowl habit- mild constipated once in two days

Micturition- normal, clear

Sleep- sound

Menstrual history

LMP- 02/03/2020

13-15days/irregular

1st 3 days- bleeding + one pad/day

$4^{\text {th }}-15^{\text {th }}$ days- bleeding $++3-4$ pads/day

Pain ++

Clots+

Smell +

Obstetric history-

Married life -22 years

G2P2A0L2D0

L1- male 20yrs FTND

L2- female 16yrs FTND

Tubectomy not done

\section{General examination}

* Built - Moderate

* Nourishment-Moderate

* Temperature - 96.4 F

* Respiratory rate $-18 / \mathrm{min}$

* Pulse rate - 78 bpm

* B.P - 120/80 mm of Hg

* Height $-160 \mathrm{cms}$

Weight - $62 \mathrm{Kg}$

* Pallor - Absent

* Edema-Absent

* Clubbing - Absent

* Cyanosis - Absent

* Icterus - Absent

* Lymphadenopathy - Absent

* Tongue - Uncoated

Systemic examination-

CVS S1 S2 normal

CNS: Well oriented, conscious.

$>$ RS: normal vesicular breathing, no added sounds.

$>$ P/A- Soft, no organomegaly, Tenderness + in hypogastrium region

P/S- Cx healthy, no white discharge 
$\mathrm{P} / \mathrm{V}-\mathrm{AV} / \mathrm{NS} / \mathrm{FF}$

\section{Lab Investigations}

* Blood investigations

$\mathrm{Hb} \%-12$ grm $\%$

U.S.G- Bulky Uterus with features of adenomyosis $(14 / 03 / 20)$
Samprapti Ghataka -

Dosha - Vata Pradhana Pitta

Dushya-Rasa and Rakta

Srotas involved- Aartava Vaha Srotas

Srotodushthi- Atiprivriti

Nidana (Ahara and Vihara as patient was taking more Rukshapradhana, Katu Lavana Pradhana - spicy and salty and more nonveg)

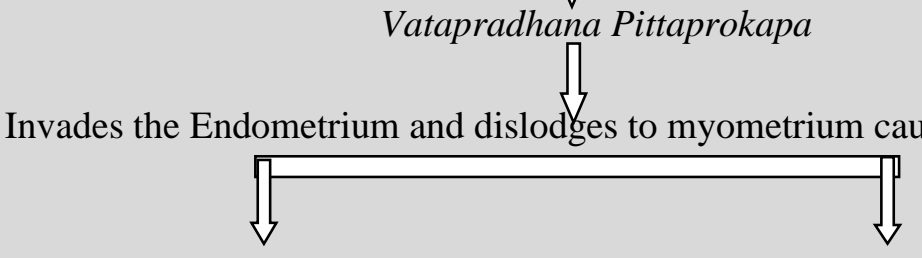

\section{Nityam Vedana (because of Vata Prokopaka)}

(Blood gets trapped and cannot exit out of body and irritates the surrounding tissues)

\section{Atipravriti Of Aartava (because of pita Prokopa)}

(Menorrhagia due to inflammation, neuroangiogenesis, proliferation

\section{Intervention-}

Abhyantara Chikitsa (Shamana Chikitsa)

$\left.\begin{array}{|l|l|l|l|}\hline \text { Name of medicine } & \text { Dose } & \text { Duration } \\ \hline \text { 1) Usheerasava } & 15 \mathrm{ml} \mathrm{BD} & \text { For two months } \\ \hline 2 \text { Chandnasava } & 15 \mathrm{ml} \mathrm{BD} & \text { For two months }\end{array}\right\} \begin{aligned} & \text { stopped this treatment after two } \\ & \text { months }\end{aligned}$

Then started with

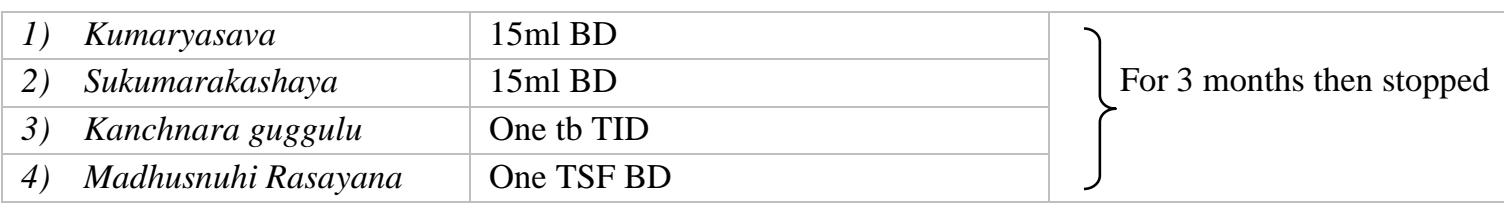

\section{Follow up and outcome-}

After the treatment, advised follow up after 2 months without any medication.

USG was done in the follow up period showed promising result. 


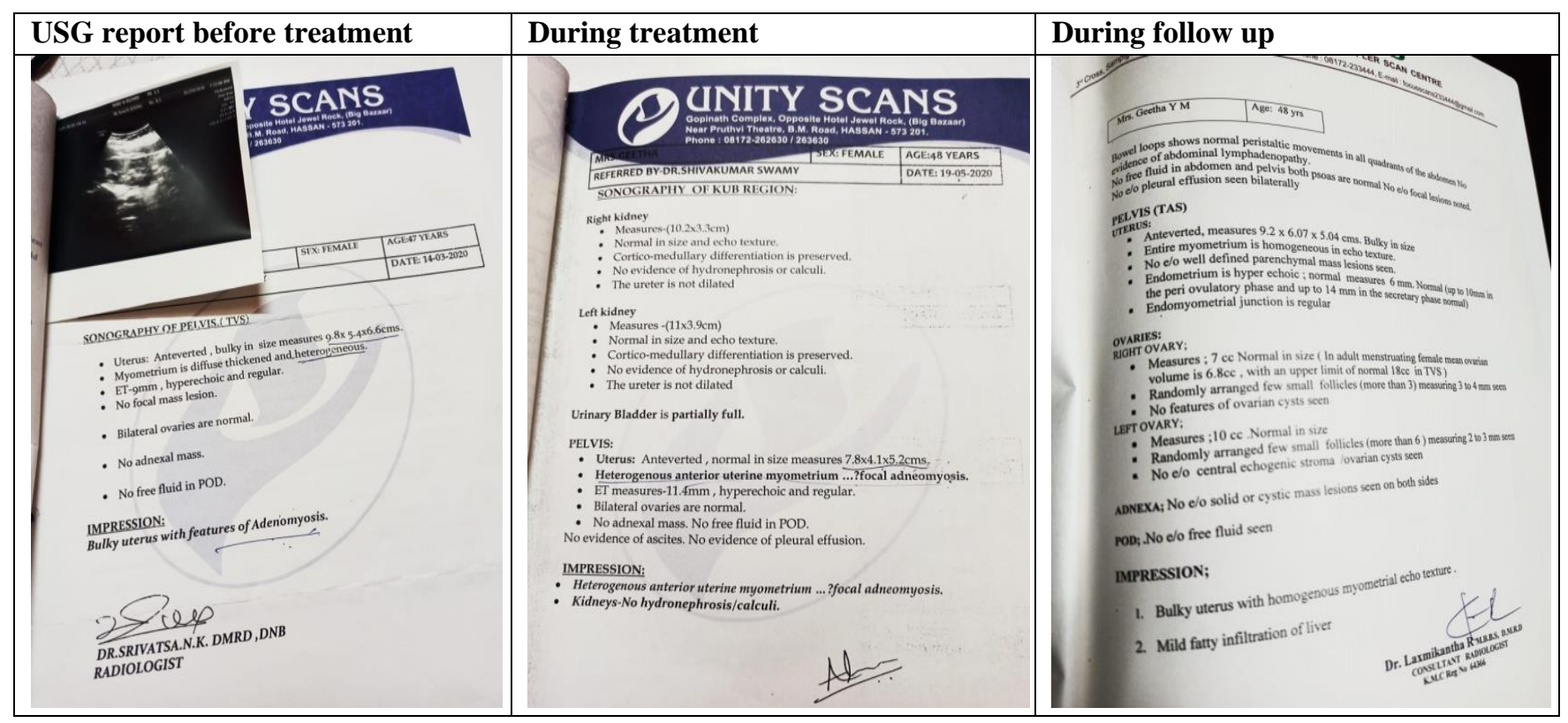

\section{DISCUSSION}

The case was diagnosed as Adenomyosis. It is often asymptomatic. Symptoms typically associated with Adenomyosis include heavy and prolonged menstrual bleeding and dysmenorrhea, Acharya Sushruta advocates Madhura Rasa drugs as the specific treatment of Vipluta Yoni Vyapat. In this case, Usheerasava and Chandnaasava were selected, for regularizing the menses and to reduce the quantity of menstrual flow. As Usheraasava and Chandanaasava are Shitapradhana Yogas, which are Raktapittahara in nature and also Balapustikara. Both these Yogas help in normalizing the pitta and helps in Dhatupusti. Once the patient regained normal menses for two consecutive cycles, she was then advised to stop Chandanasava and Usheerasava and started with Kanchanara Guggulu, Kumaryasava, Sukumarkashaya and Madhusnuhi Rasayana. Kanchanara Guggulu which helps in Granthi Vilayana and is Vranahara i.e. helps in decreasing the size of Granthi and Vrana. Kumaryasava is Raktapittahara and Vatanulomaka Brimhana, Rechana which in term helps correction of the Vata and Pitta. Sukumarkashayam indicated in Udavarthini, Granthi and in Artava Dusti, also has antispasmodic property. The main content of Madhusnuhi Rasayana is Chopachini and it acts as a Nitya Virechaka and Vatapittahara.

Chandnasaasava and Usheerasava are best Raktapittasamaka Yogas. So, it is given to regularize the menses, continued till two consecutive cycles. Kumaryasava and Sukumara Kashaya are Vata Shamaka Pitta Shamaka and Vata Anulomaka and also helps in regularizing the menses. In this case there is Vata and Pitta involvement noted, hence this combination will normalize the function of Vata and Pitta. if Vata is in its Prakrutha Avastha, it does its normal function, the Vataprakopaka Lakshanas disappears i.e. Vedana (dysmenorrhoea). Adenomyosis is described as circumscribed nodular aggregates of smooth muscles, hence it looks like Granthi. Kanchanara Guggulu works as Granthihara and decrease its size. Madhu Snuhi Rasayana act as Nitya Virechaka which helps in removing excess pitta dhatu as it is indicated in Raktadhatudushthi.

Considering above points we planned to normalize the functioning of Vata and pitta (Samprapti Vighatana. Madhusnuhi Rasayana was chosen to act as Bala Pusthikara and Vrishya.

\section{CONCLUSION}

Ayurveda is a holistic science in which root cause of disease is treated. In this study promising result were obtained and the same study can be conducted on a large group of population which will be beneficial for the society. 


\section{REFERENCES}

1. Salhan Sudha, Textbook of Gynecology: 2011, New Delhi, Jaypee Brothers Medical Publishers, Pn 328

2. Sushruta Samhita With Nibhandasangraha Commentary of Dhalhanacharya, Choukambha Sanskrith Sansthana 2010 Uttara Tantra Adhyaya 38/10 Pp 824s.

3. Govinddas Sen. Bhaishajya Ratnavali. Shasthri VA,Editor. Ist Ed.Varanasi: Chaukamba Krishnadas Academy, Raktapitta Prakrana 13.

4. Govinddas Sen. Bhaishajya Ratnavali. Shasthri VA,Editor. Ist Ed.Varanasi:Chaukamba Krishnadas Academy, Sukrameha Prakrana 34-38.

5. Govinddas Sen. Bhaishajya Ratnavali. Shasthri VA,Editor.Ist Ed. Varanasi: Chaukamba Krishnadas Academy, Galaganda Roga Chikitsa 44/64-69.

6. Sharangdhara, Sharangdhara Madhyamkhanda 10/1827.

7. Sahasrayoga, Kashayam Yoga Prakrana

8. Sahasrayoga Lehya Prakrana.

\section{Source of Support: Nil Conflict of Interest: None Declared \\ How to cite this URL: Shivakumaraswamy P et al: Ayurvedic Management of Adenomyosis - A Case Report. International Ayurvedic Medical Journal \{online\} 2021 \{cited May, 2021\} Available from: http://www.iamj.in/posts/images/upload/2960_2964.pdf}

